\title{
Performance and Meat Quality of Broilers Infected with Escherichia coli and Administered with Bio Additive, Probiotic, and Antibiotic
}

\author{
L. Istiqomah ${ }^{\mathrm{a}, *}$, S. N. Hayati ${ }^{\mathrm{a}}$, E. Damayanti ${ }^{a}$, H. Julendra ${ }^{a}$, A. A. Sakti ${ }^{a}$, \& T. Untari $^{\mathrm{b}}$ \\ ${ }^{a}$ Research Unit for Processes Development \& Chemical Engineering (UPT. BPPTK), Indonesian Institute of Sciences (LIPI) \\ Jln. Jogja - Wonosari Km. 31, Gading, Playen, Gunungkidul, Yogyakarta 55861, Indonesia \\ ${ }^{b}$ Laboratory of Microbiology, Faculty of Veterinary Medicine, Gadjah Mada University \\ Sekip Unit II, Yogyakarta 55281, Indonesia \\ (Received 01-11-2012; Reviewed 19-12-2012; Accepted 25-03-2013)
}

\begin{abstract}
An experiment was conducted to determine the efficacy of bio additive administration (a mixture of Lumbricus rubellus extract, Morinda citrifolia leaves extract and lactic acid bacteria), probiotic, and antibiotic to the performance and meat quality of broiler infected with Avian Pathogenic Escherichia coli (APEC). In this study, 140 Jumbo 747 unsexed one-day old chicks were distributed randomly into 20 units of cages, each filled with 7 broilers. Twenty cages were assigned into 5 treatment groups, each treatment in 4 equal replicates. The treatments were as follows: $A=E$. coli infection (positive control), $B=E$. coli infection + bio additive, $\mathrm{C}=E$. coli infection + probiotic, $\mathrm{D}=E$. coli infection + antibiotic, $\mathrm{E}=\mathrm{No} E$. coli infection (negative control). A commercial corn-soybean-based broiler diet was formulated as the basal diets. The experimental period was $35 \mathrm{~d}$ and at $21^{\text {st }} \mathrm{d}$ of age the broilers were infected with E. coli except the $E$ treatment. The result showed that bio additive administration (B) increased the final body weight $(1,659.52 \mathrm{~g})$ and body weight gain $(1,616.81 \mathrm{~g})$ and resulted in less FCR (1.87) among other treatments. The lowest mortality rate was recorded in B treatment (3.57\%) and D treatment $(3.57 \%)$. Probiotic (C treatment) and antibiotic ( $\mathrm{D}$ treatment) decreased $(\mathrm{P}<0.05)$ meat $\mathrm{pH}$ and tenderness compared to other treatments. Meanwhile bio additive administration did not affect the meat quality ( $\mathrm{pH}$, cooking loss, water-holding capacity, tenderness, and fat) compared to positive and negative controls. The lowest meat cholesterol content was observed in B treatment $(54.02 \mathrm{mg} / 100 \mathrm{~g})$. It is concluded that bio additive administration on broiler infected with $E$. coli increased the broiler performance and decreased the meat cholesterol compared to other treatments.
\end{abstract}

Key words: bio additive, probiotic, antibiotic, E. coli, broiler performance

\section{ABSTRAK}

Penelitian dilakukan untuk mempelajari pengaruh pemberian bio aditif (campuran ekstrak cacing tanah Lumbricus rubellus, ekstrak daun mengkudu Morinda citrifolia dan bakteri asam laktat), probiotik, dan antibiotik terhadap performa dan kualitas daging ayam broiler yang diinfeksi avian pathogenic Escherichia coli (APEC). Sebanyak 140 ekor DOC 747 Jumbo didistribusikan secara acak ke dalam 20 unit kandang, masing-masing diisi dengan 7 ekor ayam. Dua puluh kandang tersebut dibagi ke dalam 5 kelompok perlakuan, tiap perlakuan terdiri atas 4 ulangan. Kelompok perlakuan terdiri atas perlakuan $\mathrm{A}=$ infeksi E. coli (kontrol positif), B= infeksi $E$. coli + bio aditif, $\mathrm{C}=$ infeksi $E$. coli + probiotik, $\mathrm{D}=\mathrm{infeksi} E$. coli + antibiotik, E= tanpa infeksi E. coli (kontrol negatif). Pakan komersil berbasis jagung-kedelai diformulasi sebagai pakan basal. Percobaan dilakukan selama 35 hari dan pada hari ke-21 broiler diinfeksi $E$. coli kecuali perlakuan E. Hasil penelitian menunjukkan bahwa pemberian bio aditif (B) menghasilkan berat badan akhir $(1.659,52 \mathrm{~g})$ dan pertambahan bobot badan $(1.616,81 \mathrm{~g})$ yang lebih tinggi $(\mathrm{P}<0,05)$ serta FCR yang lebih efisien $(1,87)$ dibandingkan perlakuan lainnya. Tingkat kematian terendah tercatat pada perlakuan $\mathrm{B}(3,57 \%)$ dan $\mathrm{D}(3,57 \%)$. Pemberian probiotik dan antibiotik menurunkan $(\mathrm{P}<0,05) \mathrm{pH}$ dan keempukan daging dibandingkan dengan perlakuan lainnya. Sementara itu, pemberian bio aditif tidak mempengaruhi kualitas daging $(\mathrm{pH}$, susut masak, kapasitas menahan air, keempukan, dan kadar lemak daging) dibandingkan dengan kontrol positif dan negatif. Kolesterol daging terendah tercatat pada perlakuan B (54,02 mg/100 g). Dapat disimpulkan bahwa pemberian bio aditif pada broiler yang diinfeksi $E$. coli dapat meningkatkan performa ternak dan menurunkan kolesterol karkas dibandingkan perlakuan lainnya.

Kata kunci: bio aditif, probiotik, antibiotik, E. coli, performa broiler 


\section{INTRODUCTION}

Avian colibacillosis is an infectious disease of birds caused by avian pathogenic E. coli (APEC), which is considered as one of the principal causes of high morbidity and mortality, associated with heavy economic losses to the poultry industry by its association with various disease conditions, either as primary pathogen or as a secondary pathogen (Kabir, 2010). Due to prohibition of antibiotics application as growth promoters (AGP's) and sub therapeutic use in animal feed industry since 2006 in European Union (EU) and the possibility of a ban in other countries, the importance of functional natural materials in poultry diets have increased attention in recent years. The natural materials may replace the AGP's are pre- and probiotic, bacteriocins, organic acids, essential oils, herbs and spices (plant extracts), yeast cultures, oligosaccharides, and flavourings (Gaggia et al., 2010). Earthworm (Lumbricus rubellus) meal is one of natural feed additive used for this purpose. Cho et al. (1998) reported the antibacterial activity of earthworm L. rubellus in broad spectrum against some pathogenic bacteria due to its bioactive compound 'lumbricin I' and chemotherapeutic components of lumbrokinase and fibrinolytic enzymes.

There is global interest in harnessing bioactive properties of plants and their secondary compounds as alternatives to chemical, drugs and growth promoters (Durmic \& Blache, 2012). Noni (Morinda citrifolia) leaf is an herbal plant containing anthraquinone compound as an antibacterial. This compound has been shown to fight against infectious bacteria strains such as Pseudomonas aeruginosa, Proteus morgaii, Staphylococcus aureus, Bacillus subtilis, Escherichia coli, Salmonella, and Shigela (Deshmukh et al., 2011).

A number of new probiotic strains of lactic acid bacteria have been developed and have benefits to animal and human health, including increased protection against intestinal pathogens and modulate the immune system (Crittenden et al., 2005). Probiotic enhanced the systemic antibody response to some antigens in broiler chickens (Haghigi et al., 2005), promoted the poultry meat quality (Kabir, 2009), increased the body weight, decreased feed conversion ratio, and reduced coliforms number in the ileum (Taheri et al., 2010).

This study focused on determining the effect of drinking water administered by earthworm extract, noni leaves extract and lactic acid bacteria (bio additive) on growth performance and meat quality of broiler infected with Avian Pathogenic Escherichia coli (APEC).

\section{MATERIALS AND METHODS}

\section{Bio Additive}

Bio additive material contained earthworm meal extract, noni (M. citifolia) leaves extract, and dry culture of lactic acid bacteria.

Preparation and extraction of earthworm meal. Preparation of earthworm meal refers to the modified methods of Edwards (1985). Earthworms were separated from the media and then washed with water to remove dirt and grime on the outer skin digestive tract (fecal mud) of the worm. Then worms soaked in cold water $4{ }^{\circ} \mathrm{C}$ for $24 \mathrm{~h}$. Formic acid $80 \%$ was added as much as $3 \%$ by weight of the worms. The worm was milled using a blender to become a paste and the paste was dried in an oven at 50 ${ }^{\circ} \mathrm{C}$ for $12 \mathrm{~h}$ and sieved to obtain a homogeneous particle size of \pm 40 mesh. Earthworm extract was prepared by the dekokta extraction method with water at $90{ }^{\circ} \mathrm{C}$ for 30 min (Ministry Health of RI, 2000). One part of the earthworm meal and 10 parts of water were heated and then filtered using a filter cloth. The filtrate was concentrated by evaporation until a thick consistency.

Preparation and extraction of noni leaves powder. Mature noni leaves were collected from Playen Gunungkidul area, then washed and dried in an oven at 50-60 ${ }^{\circ} \mathrm{C}$, ground and sieved to 30 mesh of particle size. Leaves powder was soaked in $40 \%$ ethanol for $3 \mathrm{~d}$ with occasional stirring, placed in a cool place, and protected from the sun light. Filtrate obtained was evaporated over a water bath and blew with a fan until a thick consistency material was obtained.

Granulation of noni leaves and earthworm meal extracts. The granulation of noni leaves and earthworm meal extracts was performed by wet granulation method. Thick crude extract of earthworm meal were blended with drying agent, Manihot starch. Then, the second active ingredient (noni leaves extract) was added. Sucrose was added into the mixture as a filling agent. The last material added into the mixture was carboxymethyl cellulose (CMC-Na) as a suspending agent. The wet mass sieved to 20 mesh of particle size and dried at $40-60{ }^{\circ} \mathrm{C}$ for 24-48 h. The dry mass then sieved again to 20 mesh of particle size.

Preparation of dry cultures of lactic acid bacteria. Probiotic was prepared by microencapsulation methods using spray dryer (Lab Plant SD-Basic) according to Barbosa-Canovas (2005). Probiotic selected isolate (Pediococcus acidilactici RO1) was cultivated in de Man Rogosa Sharpe (MRS) Broth media at $37^{\circ} \mathrm{C}$ for $18 \mathrm{~h}$. The culture was centrifuged at $4500 \mathrm{rpm}$ for $10 \mathrm{~min}$, then the biomass / pellet was mixed with skim solution $(20 \% \mathrm{w} /$ $\mathrm{v})$ and gum arabic $(1 \% \mathrm{w} / \mathrm{v})$. The solution was homogenized using a homogenizer at $8000 \mathrm{rpm}$ for $5 \mathrm{~min}$ before microencapsulation process. Spray dryer operating conditions as follows: inlet air temperature $110^{\circ} \mathrm{C}$, outlet air temperature $68{ }^{\circ} \mathrm{C}$, and the speed of pump 3. Dried cultures of probiotic that obtained from spray dryer then added with skim as fillers and adjusted to $1 \times 10^{9} \mathrm{cfu} / \mathrm{g}$ of cell density.

Formulation of bio additive. Earthworms extract, noni leaves extract, starch, sucrose, and CMC-Na (200: 200 : $200: 2,836: 564 \mathrm{mg} / \mathrm{kg} \mathrm{BW}$ ) were mixed homogenously and then be mixed with dried cultures of probiotic $\left(1 \times 10^{9}\right.$ $\mathrm{cfu} / \mathrm{g}$ ) to produce granule form called bio additive. Dose of bio additive used in this study was $4 \mathrm{~g} / \mathrm{kg} \mathrm{BW}$.

Antibiotic oxytetracycline used in this study was in a mixed form with multivitamins (vitamin A, D3, E, 
K3, B1, B2, B6, B12, and C), nicotinic acid, and calciumD-pantothenate. Dose of antibiotic used was $0.71 \mathrm{~g} / \mathrm{L}$ of drinking water. Probiotic applied in this study contained $1 \times 10^{12} \mathrm{cfu} / \mathrm{g}$ of Lactobacillus acidophillus, Bacillus subtilis, Bacillus megaterium, Lactobacillus bulgaricus, Candida pintolopesii, Saccharomyces cerevisiae, Aspergillus oryzae, and Streptococcus thermophillus. Dose applied was $0.5 \mathrm{ml} / \mathrm{L}$ of drinking water.

\section{Experimental Diet}

Basal diet composed of rice bran, pollard, fish meal, crude palm oil, calcium carbonate $\left(\mathrm{CaCO}_{3}\right)$, di calcium phosphate (DCP), lysine, DL-methionine, commercial premix and formulated to meet nutrient requirements of broilers as recommended by NRC (1994) (Table 1). The protein level of the diets was approximately $22 \%-23 \%$. Nutrient content of diet based on laboratory analyses.

\section{Determination of $E$. coli Dose}

To determine the infectious dose-50 ( $\left.\mathrm{ID}_{50}\right), 20$ broiler chicks were kept separately from others from DOC. In the early stages DOC intracardiac blood samples were taken to ensure the DOC were free from E. coli. Escherichia coli used in this study was Avian Pathogenic Escherichia coli (APEC). At 3-wk old, the broilers were infected with $E$. coli orally with a serial doses of $10^{6}, 10^{7}$,

Table 1. Composition and nutrient content (DM basis) of the basal diets used in the experiment

\begin{tabular}{|c|c|c|c|}
\hline Ingredients & \multicolumn{3}{|c|}{ Composition (\%) } \\
\hline Ground yellow corn & \multicolumn{3}{|c|}{62.55} \\
\hline Rice bran & \multicolumn{3}{|c|}{1.00} \\
\hline Pollard & \multicolumn{3}{|c|}{3.25} \\
\hline Soybean meal & \multicolumn{3}{|c|}{23.00} \\
\hline Fish meal & \multicolumn{3}{|c|}{7.50} \\
\hline Crude palm oil & \multicolumn{3}{|c|}{1.00} \\
\hline $\mathrm{CaCO} 3$ & \multicolumn{3}{|c|}{0.50} \\
\hline DCP & \multicolumn{3}{|c|}{0.10} \\
\hline L-lysine & \multicolumn{3}{|c|}{0.80} \\
\hline DL-methionine & \multicolumn{3}{|c|}{0.27} \\
\hline Commercial premix & \multicolumn{3}{|c|}{0.03} \\
\hline Total & \multicolumn{3}{|c|}{100.00} \\
\hline \multirow{2}{*}{ Nutrient content: } & Broiler diets & \multicolumn{2}{|c|}{ Broiler diets requirements } \\
\hline & $\begin{array}{l}\text { Starter- } \\
\text { Finisher }\end{array}$ & Starter & Finisher \\
\hline Moisture (\%) & 10.91 & 10.00 & 10.00 \\
\hline Crude protein (\%) & 22.68 & 23.00 & 20.00 \\
\hline Fat $(\%)$ & 4.48 & $\max .7 .40$ & $\max .8 .00$ \\
\hline Crude fiber (\%) & 2.56 & $\max .6 .00$ & $\max .6 .00$ \\
\hline Ash (\%) & 4.62 & $\max .8 .00$ & $\max .8 .00$ \\
\hline $\mathrm{Ca}(\%)$ & 1.99 & 1.00 & 0.90 \\
\hline $\mathrm{P}(\%)$ & 0.38 & 0.50 & 0.40 \\
\hline
\end{tabular}

1) National Research Council (1994)
$10^{8}, 10^{9} \mathrm{cfu} / \mathrm{ml} / \mathrm{bird}$ and then kept for $14 \mathrm{~d}$ to observe clinical symptoms and the death of chickens. E. coli was isolated from died chickens or that indicating clinical symptoms to confirm the cause of the disease (Radji et al., 2003). Infection dose $\left(\mathrm{ID}_{50}\right)$ was determined by modified method of Reed \& Muench (1938).

\section{In Vivo Experiment}

A total number of 140 Jumbo 747 unsexed one-day old broilers with initial body weight of 42-43 g were allocated randomly into 5 treatments. All birds kept under a similar condition of management throughout the experimental period lasting for $35 \mathrm{~d}$ of age. Initial brooding temperature was $33^{\circ} \mathrm{C}$ in the first week of age and reduced gradually $2{ }^{\circ} \mathrm{C}$ per wk to $24{ }^{\circ} \mathrm{C}$. Diets and water were provided ad libitum all over the experimental period. Nutrient content of the experimental diet is presented in Table 1 . The experiment was designed in a completely randomized design with 5 treatments, with 4 equal replicates and 7 broiler chicks each. The treatments tested on broiler chickens were as follows: $A=E$. coli infection (positive control), $\mathrm{B}=E$. coli infection + bio additive, $\mathrm{C}=E$. coli infection + probiotic, $\mathrm{D}=E$. coli infection + antibiotic, $\mathrm{E}=\mathrm{No}$ E. coli infection (negative control).

Bio additive, probiotic, and antibiotic were given every day through drinking water. Vaccinations were given at the age of $4 \mathrm{~d}$ old (ND-IB vaccine, Newcastle Disease, Infectious Bronchitis-eye drops), $10 \mathrm{~d}$ old (IBD vaccine, Infectius Bursal Disease), and $15 \mathrm{~d}$ old (ND Lasota vaccine, Newcastle Disease-oral). At the age of $21 \mathrm{~d}$ old (6 d post-vaccination ND Lasota) the E. coli was infected to broilers orally with dose $10^{8} \mathrm{cfu} / \mathrm{ml} / \mathrm{bird}$ (based on $\mathrm{ID}_{50}$ ). The appearance of clinical symptoms was observed one week after infection. Necropsy was conducted on the chicks with the symptom to see macroscopic (PA) and microscopic (histopathology) changes, and blood profiles. At the end of experimental period, twenty chickens (4 chickens per treatment) were randomly selected, weighed, and slaughtered to evaluate the meat quality.

\section{Growth Performance and Meat Quality of Broilers}

Growth performance. Feed intake was recorded daily by subtracting the amount of offered feed with the residual feed for each replicate. Final body weight was assessed basis from initial day to the final day of the experiment. Mortality was recorded daily, and percentage of mortality was calculated. Feed conversion ratio (FCR) was calculated as total feed intake divided by final body weight of live chicken (Timmerman et al., 2006).

Meat quality. At the end of experiment (35 day of age) one bird per replication were randomly slaughtered for meat quality analysis ( $\mathrm{pH}$, cooking loss, water holding capacity, tenderness, fat, and cholesterol content). The breast muscles (without skin) were used for physical quality analysis $(\mathrm{pH}$, cooking loss, water holding capacity, and tenderness), while the thigh muscles were used for fat and cholesterol determination. The meat $\mathrm{pH}$ was measured according to Soewedo (1994). The meat 
samples were mashed with meat grinder, as much as $2 \mathrm{~g}$ sample diluted with $18 \mathrm{ml}$ of distilled water and stirred until homogeneous then filtered. The filtrate samples were measured with a $\mathrm{pH}$ meter (HI 9811X Piccolo, Hanna instrument).

Cooking loss was determined according to Nikmaram et al. (2011). Meat samples (20 g) were placed in polyethylene plastic, then sealed with vaccumpack, and heated in a water bath at $80{ }^{\circ} \mathrm{C}$ for $30 \mathrm{~min}$. After cooked, samples were cooled at room temperature, dried surface with filter paper, reweighed using an analytical balance (Metler AE100-0.001), and the cooking loss calculated from differences in raw and cooked weight.

Water holding capacity was determined according to Hamm method (1960). Meat samples (0.3 g) were placed on Whatman 41 filter paper between two metal plates with a pressure load of $35 \mathrm{~kg}$ for 5 min until wet area formed on the filter paper. Wet area was calculated by subtracting the area covered meat samples (in the area of a circle) of the total area (wide outer ring).

Tenderness was measured according to Soeparno et al. (2005). Meat samples were sealed in polypropylene plastic, then heated in a water bath at $80^{\circ} \mathrm{C}$ for $30 \mathrm{~min}$. After cold, samples were made with a size of $1.5 \times 0.67$ $\mathrm{cm}$ or tubular shape, and placed on Wanner-Blaztser Shear Force, Model Salter 235. Samples were cut parallel to the muscle fiber direction and measurement result was noted. Fat content of the breast was measured by extraction in a Soxhlet apparatus with petroleum ether (AOAC, 1990). Total fat were extracted from the samples (about $4 \mathrm{~g}$ ) with $40 \mathrm{ml}$ chloroform:methanol (2:1, vol/vol) in a $50 \mathrm{~mL}$ ground-glass extraction flask according to the method of Folch et al. (1957). The meat cholesterol content was determined by Liebermann-Burchad reaction (Kenny, 1952) using a spectrophotometer at a wavelength of $420 \mathrm{~nm}$. Coloring reagent used were acetic acid anhydride and concentrated sulfuric acid in different solvents such as chloroform or ether.

\section{Statistical Analysis}

The effect of treatments on broiler performance and meat quality were evaluated using the analysis of variance of a completely randomized design and the differences among mean treatments were analyzed using Duncan's Multiple Range Test (Gomez \& Gomez, 2007).

\section{RESULTS AND DISCUSSION}

\section{Broilers Performance}

The initial live weight indicated that DOC were distributed well within the experimental treatments. There were no difference on body weight, weight gain, feed intake, FCR, and mortality between infected (A treatment) and uninfected broilers (E treatment) (Table 2). The changes in body weight, weight gain and FCR were not good indicators of the infection of E. coli. Teo \& Tan (2006) reported the similar result that E. coli challenged broilers did not indicate changes in body weight, weight gain, and FCR.

Broilers supplemented by bio additive (B treatment) had the highest final body weight and body weight gain $(\mathrm{P}<0.05)$ and the lowest feed conversion ratio. Bio additive might have growth promoter effect and reduce the negative effect of the presence of E. coli in broiler. Teo \& Tan (2006) observed an increasing trend in weight gain and improved FCR of broilers challenged by E. coli and supplemented by $B$. subtilis (probiotic) compared with those in antibiotic. Alkhalf et al. (2010) reported that 0.8$1.0 \mathrm{~g} / \mathrm{kg}$ diet of probiotic supplementation significantly increased the body weight and daily weight gain of broiler chicks for growth period of 3-6 wk and also improved feed conversion. Taheri et al. (2010) reported that $P$. acidilactici supplementation $\left(10^{8} \mathrm{cfu} / \mathrm{g}\right.$ diet $)$ on broilers diet increased body weight and decreased FCR $(\mathrm{P}<0.05)$. Ton et al. (2009) reported that chicken fed diet supplemented with $2 \%$ red worm had the highest live weight at 10 wk (1,925 g) and better FCR (2.95). Sofyan et al. (2010) confirmed that earthworm meal supplementation $(25 \%)$ increased final body weight $(1,635.4 \mathrm{~g})$ and body weight gain $(1,393.5 \mathrm{~g})$, reduced feed intake $(1,886.5 \mathrm{~g})$ and FCR (1.36). Gunnal et al. (2006) reported that live weight gain, feed intake, feed conversion ratio and mortality were not affected by basal diet throughout supplemented probiotic ( $0.1 \%$ protexin) and antibiotic growth promoter (0.1\% flavomycin). In contrast, Murwani et al. (2011) stated that body weight of broiler fed corn-mungbean basal diet supplemented yeast and noni leaf extract was lower than control.

The improvement in the body weight, daily weight gain, and feed conversion in this study may be also due to the presence of $P$. acidilactici which increased

Table 2. Growth performance of broiler offered diets with different administration of additive at $35 \mathrm{~d}$ of age

\begin{tabular}{|c|c|c|c|c|c|}
\hline \multirow{2}{*}{ Observed variable } & \multicolumn{5}{|c|}{ Treatments } \\
\hline & $\mathrm{A}$ & $\mathrm{B}$ & $\mathrm{C}$ & $\mathrm{D}$ & $\mathrm{E}$ \\
\hline Initial BW (g) & $42.43 \pm \quad 0.80$ & $42.71 \pm \quad 0.76$ & $42.21 \pm \quad 1.05$ & $43.46 \pm 1.96$ & $42.68 \pm \quad 0.87$ \\
\hline Final BW (g) & $1,230.28 \pm 125.44^{\mathrm{a}}$ & $1,659.52 \pm 127.75^{b}$ & $1,121.29 \pm 133.79^{a}$ & $1,280.56 \pm 117.27^{a}$ & $1,158.74 \pm 63.26^{a}$ \\
\hline BWG (g) & $1,187.85 \pm 125.31^{\mathrm{a}}$ & $1,616.81 \pm 127.52^{b}$ & $1,079.08 \pm 132.86^{\mathrm{a}}$ & $1,237.10 \pm 117.70^{\mathrm{a}}$ & $1,116.06 \pm 63.13^{a}$ \\
\hline Feed intake (g) & $2,782.86 \pm 263.53$ & $3,119.24 \pm 543.02$ & $3,125.87 \pm 1,085.95$ & $2,662.61 \pm 250.98$ & $2,864.70 \pm 666.27$ \\
\hline FCR & $2.27 \pm \quad 0.27$ & $1.87 \pm \quad 0.21$ & $2.85 \pm \quad 1.20$ & $2.09 \pm \quad 0.20$ & $2.49 \pm \quad 0.67$ \\
\hline Mortality (\%) & $4.46 \pm$ & $3.57 \pm \quad 2.92$ & $8.04 \pm$ & $3.57 \pm \quad 2.92$ & $5.36 \pm$ \\
\hline
\end{tabular}

Note: Means in the same row with different superscript differ significantly $(\mathrm{P}<0.05) . \mathrm{A}=E$. coli infection; $\mathrm{B}=E$. coli infection + bio additive; $\mathrm{C}=E$. coli infection + probiotic; $\mathrm{D}=$ E. coli infection + antibiotic; $\mathrm{E}=$ No E. coli infection. 
efficiency of digestion and nutrient absorption processes. Edens (2003) reported that the inclusion of desirable microorganisms (probiotics) in the diet allows the rapid development of beneficial bacteria in the digestive tract of the host, improving its performance. As a consequence, there is an improvement in the intestinal environment, increasing the efficiency of digestion and nutrient absorption processes. The beneficial effects of probiotic might also be related to general properties of probiotic such as lactic acid and enzyme production, competitive exclusion against pathogens and increase of villus height of intestine. Beside that, the improvement of performance may also due to the efficiency of undigested feed in the earthworm administration so that energy intake fully utilized by the body for life and growth as well as survival of the animals (McDonald, 2002). Earthworm meal L. rubellus contained $63.08 \%$ protein and $18.51 \%$ fat (of dry mass) (Damayanti et al., 2008) that meet the nutrition requirement of poultry. Therefore, chickens consumed smaller quantity of feed and had great growth.

Feed intake of broiler administered bio additive was not significantly different from that of broilers fed basal diets. Bio additive did not reduce the high variations in feed intake and FCR values, which might be due to the mash form of the experimental diet. Jahan et al. (2006) reported that broilers fed mash had lower performance than broilers fed pellet form and crumble. Salari et al. (2006) confirmed that chickens fed pelleted diets, consumed more feeds and showed better weight gain and FCR.

The mortality percentages of broilers with E. coli infection within bio additive treated group (B) and antibiotic (D) were lower $(3.57 \%)$ than positive control $(4.46 \%)$, negative control (5.36\%) and probiotic (7.14\%). Bio additive indicated an ability to reduce the negative effect of E. coli. Huff et al. (2012) reported that oral administration of probiotic reduced the mortality and increased weight gain of broiler challenged by APEC infection. Leaf extract (Deshmukh et al., 2011) and earthworm extracts (Cho et al., 1998; Tasiemski, 2008; Murwani et al., 2011; Damayanti et al., 2008; Istiqomah et al., 2011) exhib- ited antimicrobial activity against $E$. coli. Meanwhile the highest mortality rate was found in C treatment (7.14\%). The mortality could be as result of disease related to $E$. coli infection and avian blood parasite (Leucocytozoon) decreasing the immunity of broiler due to inflammation.

\section{Meat Quality}

Fat content of broiler in bio additive, probiotic and antibiotic treatments did not significantly different from positive and negative controls (Table 3). The supplementation of bio additive, probiotic and antibiotic did not significantly affect cooking loss and water-holding capacity of meat. Ton et al. (2009) reported that there was no significant difference in fat content and meat quality ( $\mathrm{pH}$, color, cooking loss, and water-holding capacity) due to dietary supplementation of red worms. In the contrary, Kalavathy et al. (2006) reported that administration of Lactobacillus cultures (probiotic) reduced the fat carcass of broiler. Sarker et al. (2010) also stated that addition of Salicornia herbacea (Hamcho) probiotic (SHP) in broiler diet significantly lower the crude fat content in meat than control.

The value of meat $\mathrm{pH}$ of broiler offered probiotic and antibiotic treatments was lower $(\mathrm{P}<0.05)$ than positive and negative control and also bio additive treatment (Table 3). Lower $\mathrm{pH}$ value is often associated with an increase in meat tenderness. Non-stressed birds had meat $\mathrm{pH}$ in the range of 5.96 and 6.07 (Van Laack et al., 2000), while the meat $\mathrm{pH}$ in this study ranged from 6.09 to 6.24 . The high value of $\mathrm{pH}$ caused by $E$. coli infection was likely associated with low muscle glycogen levels resulting in high meat $\mathrm{pH}$ (Maltin et al., 2003). Water-holding capacity is an important attribution of meat quality and can be measured by drip or cooking loss. Table 3 showed that the water-holding capacity and cooking loss were no significantly different among treatments. Cooking loss varied between $17.72 \%$ to $19.83 \%$. High quality meat has low cooking loss due to less nutrients loss (Soeparno, 2005). There was no significant difference in drip loss and cooking loss due to supplemented levels of worms (Ton et al., 2009). The meat tenderness of broiler

Table 3. Meat quality of broiler offered diets with different administration of additive at $35 \mathrm{~d}$ of age

\begin{tabular}{|c|c|c|c|c|c|}
\hline \multirow{2}{*}{ Observed variable } & \multicolumn{5}{|c|}{ Treatments } \\
\hline & A & B & $\mathrm{C}$ & $\mathrm{D}$ & $\mathrm{E}$ \\
\hline Moisture (\%) & $71.23 \pm 0.28^{\mathrm{a}}$ & $71.58 \pm 0.24^{\mathrm{b}}$ & $70.07 \pm 0.04^{c}$ & $70.13 \pm 0.04^{c}$ & $72.69 \pm 0.12^{\mathrm{d}}$ \\
\hline Ash (\%) & $3.94 \pm 0.16^{\mathrm{a}}$ & $3.55 \pm 0.21^{\mathrm{b}}$ & $3.63 \pm 0.10^{\mathrm{b}}$ & $3.83 \pm 0.04^{\mathrm{a}}$ & $4.19 \pm 0.01^{\mathrm{c}}$ \\
\hline Crude protein (\%) & $69.13 \pm 1.45^{\mathrm{a}}$ & $57.85 \pm 0.36^{\mathrm{b}}$ & $60.41 \pm 0.47^{c}$ & $64.70 \pm 1.97^{\mathrm{d}}$ & $70.14 \pm 1.61^{\mathrm{a}}$ \\
\hline Crude fiber $(\%)$ & $2.28 \pm 0.18^{\mathrm{a}}$ & $1.68 \pm 0.03^{\mathrm{b}}$ & $1.03 \pm 0.18^{c}$ & $2.92 \pm 0.14^{\mathrm{d}}$ & $0.63 \pm 0.02^{\mathrm{e}}$ \\
\hline Fat $(\%)$ & $7.57 \pm 1.76$ & $8.74 \pm 1.50$ & $8.89 \pm 1.00$ & $8.09 \pm 2.51$ & $7.27 \pm 1.26$ \\
\hline Value of $\mathrm{pH}$ & $6.24 \pm 0.07^{a}$ & $6.23 \pm 0.03^{\mathrm{a}}$ & $6.16 \pm 0.02^{b}$ & $6.09 \pm 0.01^{\mathrm{c}}$ & $6.10 \pm 0.02^{\mathrm{c}}$ \\
\hline Cooking loss (\%) & $17.72 \pm 1.03$ & $18.41 \pm 1.92$ & $19.83 \pm 1.68$ & $18.48 \pm 1.66$ & $19.04 \pm 0.90$ \\
\hline Water-holding capacity (\%) & $32.98 \pm 5.42$ & $34.42 \pm 3.14$ & $31.61 \pm 4.36$ & $30.11 \pm 6.63$ & $36.24 \pm 11.90$ \\
\hline Tenderness $\left(\mathrm{kg} \cdot \mathrm{cm}^{2}\right)$ & $5.79 \pm 0.07^{\mathrm{a}}$ & $5.77 \pm 0.03^{\mathrm{a}}$ & $5.71 \pm 0.02^{\mathrm{b}}$ & $5.64 \pm 0.01^{\mathrm{c}}$ & $5.65 \pm 0.02^{c}$ \\
\hline
\end{tabular}

Note: Means in the same row with different superscript differ significantly $(\mathrm{P}<0.05) . \mathrm{A}=E$. coli infection; $\mathrm{B}=E$. coli infection + bio additive; $\mathrm{C}=E$. coli infection + probiotic; $\mathrm{D}=$ E. coli infection + antibiotic; $\mathrm{E}=$ No E. coli infection. 


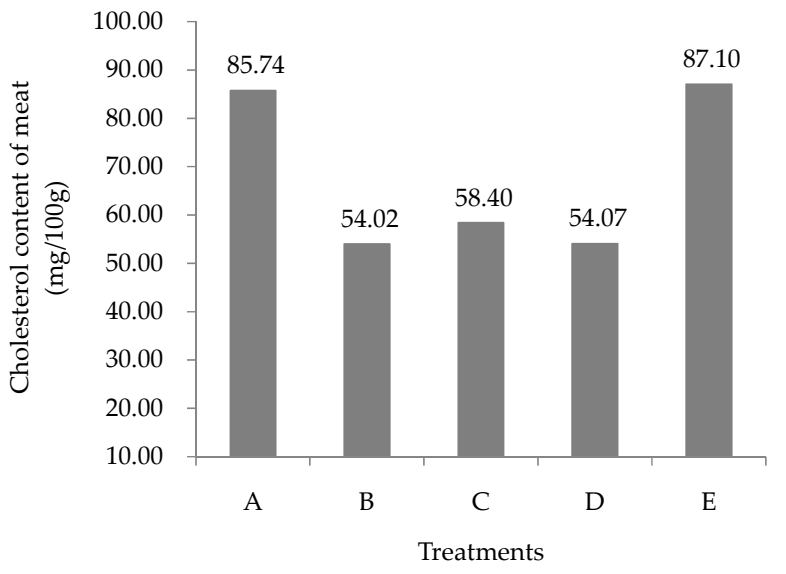

Figure 1. Cholesterol contents of broiler meat as responses to diets administered with bio additive, probiotic, and antibiotic into drinking water. $\mathrm{A}=E$. coli infection; $\mathrm{B}=$ E. coli infection + bio additive; $\mathrm{C}=E$. coli infection + probiotic; $\mathrm{D}=$ E. coli infection + antibiotic; $\mathrm{E}=\mathrm{No}$ E. coli infection.

administered probiotic and antibiotic was lower $(\mathrm{P}<0.05)$ than positive control and bio additive. Lyon et al. (2004) reported that tenderness of broiler chickens ranged between 1.82 to $2.19 \mathrm{~kg} / \mathrm{cm}^{2}$, while broiler meat tenderness in the present experiment ranged from 5.64 to 5.79 $\mathrm{kg} / \mathrm{cm}^{2}$. The level of meat tenderness due to the administration of bio additive was associated with the value of $\mathrm{pH}$. Meat with high value of $\mathrm{pH}$ was more juice and more tender (Soeparno, 2005). Zhu et al. (2010) reported that broilers muscle tenderness and cooking loss were not affected by earthworm administration. Fanatico et al. (2007) stated that drip loss and cooking loss were high in the slow-growing birds but low in the fast-growing and medium-growing birds.

Effect of bio additive, probiotic, and antibiotic administration into drinking water on cholesterol content is presented in Figure 1. Broilers given bio additive, probiotic, and antibiotic treatments produced meat with lower cholesterol content $(\mathrm{P}<0.05)$ than positive and negative control. The lowest meat cholesterol was obtained with administration of bio additive $(54.02 \mathrm{mg} / 100$ $\mathrm{g})$. The mechanism responsible for the cholesterol-lowering effect of probiotics remains unclear, but it has been suggested that the effect could be obtained through retarded cholesterol synthesis in the gastro-intestinal tract by probiotic supplementation and increased degradation of cholesterol. It was speculated that Lactobacillus acidophilus reduces the cholesterol in the blood by deconjugating bile salts in the intestine, thereby preventing them from acting as precursors in cholesterol synthesis (Abdulrahim et al., 1996). Lactobacillus has found to have a high bile salt hydrolytic activity, which is responsible for deconjugation of bile salts (Surono, 2003). Administration of Lactobacillus cultures (LC) on broiler reduced the cholesterol content of carcass by $13 \%$, since Lactobacillus cultures produced bile salt hydrolase and exhibit de-conjugating activity of bile salts, which contributed to an increased in excretion of cholesterol and reduced cholesterol in the meat of chickens (Kalavathy et al., 2006). Alkhalf et al. (2010) reported that chicken fed a diet containing probiotic had low meat cholesterol and serum (Taheri et al., 2010). Administration of fermented noni leaf reduced the cholesterol content of broiler carcass which was due to the increased in $\beta$-carotene intake (Syahruddin et al., 2011). The more $\beta$-carotene in consumption, the lower the cholesterol content of the carcass due to $\beta$-carotene inhibited Hydroksimetyl glutaryl-CoA reductase, reduced the formation of mevalonic and therefore reduced cholesterol synthesis. Murwani $e t$ al. (2011) also reported that serum cholesterol of broiler fed diet supplemented by combined baker yeast and noni leaf extract was low.

\section{CONCLUSION}

Administration of bio additive or mixed earthworms extract, noni leaves extract and lactic acid bacteria increased the growth performance, feed efficiency, and reduced meat cholesterol content of broiler infected with E. coli.

\section{REFERENCES}

Abdulrahim, S. M., M. S. Y. Haddadin, E. A. R. Hashlamoun, \& R. K. Robinson. 1996. The influence of Lactobacillus acidophilus and bacitracin on layer performance of chickens and cholesterol content of plasma and egg yolk. British Poult. Sci. 37: 341-346. http://dx.doi.org/10.1080/00071669 608417865

Alkhalf, A., M. Alhaj, \& I. Al-homidan. 2010. Influence of probiotic supplementation on blood parameters and growth performance in broiler chickens. Saudi J. Biol. Sci. 17: 219225. http://dx.doi.org/10.1016/j.sjbs.2010.04.005

AOAC. 1990. Official Methods of Analysis: Fat or ether extract in meat. 15h ed. Assoc. Off. Anal. Chem., Washington.

Barbosa-Canovas, G. V., E. Ortega-Rivas, P. Juliano, \& H. Yan. 2005. Food Powders: Physical Properties, Processing, and Functionality. Kluwer Academic/Plenum Publishers, New York.

Cho, J. H., C. B. Park, Y. G. Yoon, \& S. C. Kim. 1998. Lumbricin I, a novel proline-rich antimicrobial peptide from the earthworm: purification, cDNA cloning and molecular characterization. Acta Biochim. Biophys. Sin. 1408: 67-76. http://dx.doi.org/10.1016/S0925-4439(98)00058-1

Crittenden, R., A. R. Bird, P. Gopal, A. Henriksson, Y. K. Lee, \& M. J. Playne. 2005. Probiotic research in Australia, New Zealand and the Asia-Pacific region. Curr. Pharm. Des. 11: 37-53. http://dx.doi.org/10.2174/1381612053382304

Damayanti, E., H. Julendra, \& A. Sofyan. 2008. Antimicrobial activity of earthworm meal Lumbricus rubellus and its potency as additive in poultry feed. J. Biosfera 25: 123-128.

Deshmukh, S. R., V. P. Wadegaonkar, R. P. Bhagat, \& P. A. Wadegaonkar. 2011. Tissue specific expression of Anthraquinones, flavonoids and phenolics in leaf, fruit and root suspension cultures of Indian Mulberry (Morinda citrifola L.). Plant Omics J. 4: 6-13.

Durmic, Z. \& D. Blache. 2012. Bioactive plants and plant products: Effects on animal function, health and welfare. Anim. Feed Sci. Technol. 176: 150-162. http://dx.doi.org/10.1016/ j.anifeedsci.2012.07.018

Edens, F. W. 2003. An alternative for antibiotic use in poultry probiotics. Brazilian J. of Poult. Sci. 5: 75-97.

Edwards, C. A. 1985. Production of feed protein from animal waste by earthworms. Phil. Trans. R. Soc. Lond. B 310: 299307. http://dx.doi.org/10.1098/rstb.1985.0120

Fanatico A. C, P. B. Pillai, J. L. Emmert, \& C. M. Owens. 2007. Meat quality of slow-and fast-growing chicken genotypes 
fed low-nutrient or standard diets and raised indoors or with outdoor access. Poult. Sci. 86: 2245-2255. http://dx.doi. org/10.3382/ps.2007-00092

Folch J., M. Lees, \& G.H. Stanley. 1957. A simple method for the isolation and purification of total lipids from animal tissues, J. Biol. Chem. 226:497-509.

Gaggia, F., P. Matarelli, \& B. Biavati. 2010. Probiotics and prebiotics in animal feeding for safe food production. Int. J. Food Microb. 141: S15-S28. http://dx.doi.org/10.1016/j.ijfoo dmicro.2010.02.031

Gomez, K. A. \& A. A. Gomez. 2007. Stastitical Procedures for Agricultural Research. $2^{\text {nd }}$ ed. Translation: E. Sjamsudin \& J. S. Baharsjah. UI Press, Jakarta.

Gunnal, M., G. Yayli, O. Kaya, N. Karahan, \& O. Sulak. 2006. The effect of antibiotic growth promoter, probiotic, or organic acid supplementation on performance, intestinal microflora, and tissue of broiler. Int. J. Poult. Sci. 5: 149-155. http://dx.doi.org/10.3923/ijps.2006.149.155

Haghigi, H. R., J. Gong, C. L. Gyles, M. A. Hayes, B. Sanei, P. Parvizi, H. Gisavi, J. R. Chambers, \& S. Sahrif. 2005. Modulation of antibody-mediated immune response by probiotics in chickens. Clin. Diagn. Lab.Immunol. 12:1387.

Hamm, R. 1960. Biochemistry of meat hydration. Advances in Food Research. 10: 355-436.

Huff, G. R., W. E. Huff, C. Enders, U. Sonnenborn, N. C. Rath, M. B. Farnell, F. S. De Los Santos, \& A. M. Donoghue. 2012. Oral treatment with the probiotic Escherichia coli Nissle 1917 improves body weight and modulates the stress response of poultry in respiratory challenges with avian pathogenic E. coli. www.cabi.org/animalscience/Uploads/File/10388.pdf. [1 October 2012].

Istiqomah, L., H. Herdian, E. Damayanti, S. N. Hayati, \& H. Julendra. 2011. Inhibitory of encapsulated earthworm extract (Lumbricus rubellus) on pathogenic bacteria in vitro. Med. Pet. 35: 1-8. http://dx.doi.org/10.5398/medpet.2012.35.1.1

Jahan, M. S., M. Asaduzzaman, \& A. K. Sarkar. 2006. Performance of broiler fed on mash, pellet and crumble. Int. J. Poult. Sci. 5: 265-270. http://dx.doi.org/10.3923/ ijps.2006.265.270

Kabir, S. M. L. 2009. The role of probiotics in the poultry industry. Int. J. Mol. Sci. 10: 3531-3546. http://dx.doi.org/10.3390/ ijms 10083531

Kabir, S. M. L. 2010. Review: Avian colibacillosis and salmonellosis: A closer look at epidemiology, pathogenesis, diagnosis, control and public health concerns. Int. J. Environ. Res. Public Health 7: 89-114. http://dx.doi.org/10.3390/ ijerph7010089

Kalavathy, R., N. Abdullah, S. Jalaludin, M. C. V. L. Yong, \& Y. W. Ho. 2006. Effect of Lactobacillus feed supplementation on cholesterol, fat content and fatty acid composition of the liver, muscle, and carcass broiler chickens. Anim. Res. 55: 77-82. http://dx.doi.org/10.1051/animres:2005043

Kenny, A. P. 1952. The determination of cholesterol by the Liebermann-Burchard reaction. Biochem. J. 52(4):611-619.

Lyon, B. G., D. P. Smith, C. E. Lyon, \& E. M. Savage. 2004. Effects of diet and feed withdrawal on the sensory descriptive and instrumental profiles of broiler breast fillets. Poult. Sci. 83: 275-281.

Maltin, C., D. Balcerzak, R. Tilley, \& M. Delday. 2003. Determinants of meat quality: tenderness. Proceedings of the Nutrition Society 62: 337-347. http://dx.doi.org/10.1079/ PNS2003248

McDonald, P. 2002. Animal Nutrition. $6^{\text {th }}$ ed. Prentice Hall, London.

Ministry Health of RI. 2000. Herbal Preparations Reference. Ministry Health of the Republic of Indonesia, Jakarta.

Murwani, R., A. Indriani, I. Yuliana, K. Wihardani, M. A. Wahyuningrum, N. R. Tawakal, Mulyono, \& E. Kusu- mati. 2011. Blood biochemical indices and productivity of broilers on diet supplemented with mannan oligosacharide, baker yeast, or combined baker yeast and noni leaves extracts. Int. J. Poult. Sci. 10: 990-997. http://dx.doi. org/10.3923/ijps.2011.991.998

National Research Council. 1994. Nutrients Requirements of Poultry. $9^{\text {th }}$ rev ed. National Academy Press, Washington DC.

Nikmaram, P., M.S. Yarman, \& Z. Emamjomeh. 2011. Effect of cooking methods on chemical composition, quality and cook loss of camel muscle (Longissimus dorsi) in comparison with veal. Afr. J. Biotech. 10: 10478-10483.

Radji, M. A., J. O. Adekeye, J. K. P. Kwaga, \& J. O. O. Bale. 2003. In vitro and in vivo pathogenicity studies of Escherichia coli isolated from poultry in Nigeria. http://www.isrvma. org/article/58-1-6.htm. [1 October 2012]

Reed, L. J. \& H. Muench. 1938. A simple method of estimating fifty percent endpoints. Am. J. Hyg. 27: 493-497.

Salari, S., H. Kermanshashi, \& H. N. Moghaddam. 2006. Efect of sodium bentonite and comparison of pellet vs mash on performance of broiler chicken. Int. J. Poult. Sci. 5: 31-34. http://dx.doi.org/10.3923/ijps.2006.31.34

Sarker, S. K., S. R. Park, G. M. Kim, \& C. J. Yang. 2010. Hamcho (Salicornia herbacea) with probiotics as alternative to antibiotic for broiler production. J. Med. Plants Res. 4: 415-420.

Soeparno. 2005. Meat Science and Technology. $4^{\text {th }}$ ed. Gadjah Mada University Press, Yogyakarta.

Soewedo, H. 1994. Theory and Technology of Meat. Gajah Mada University Press, Yogyakarta.

Sofyan, A., H. Julendra, E. Damayanti, B. Sutrisno, \& M. H. Wibowo. 2010. Performance and histopathology of broiler chicken infected with Salmonella pullorum after supplementation of feed additive contain earthworm meal (Lumbricus rubellus). Med. Pet. 33: 31-35.

Surono. 2003. In vitro probiotic properties of indigenous Dadih lactic acid bacteria Asian-Aust. J. Anim. Sci. 16:726-731.

Syahruddin, E., H. Abbas, E. Purwati, \& Y. Heryandi. 2011. Effect of fermented noni leaf (Morinda citrifolia L.) in diets on cholesterol content of broiler chicken carcass. JITV 16: 266271.

Taheri, H. R., H. Moravej, A. Malakzadegan, F. Tabandeh, M. Zaghari, M. Shivazad, \& M. Adibmoradi. 2010. Efficacy of Pediococcus acidlactici-based probiotic on intestinal Coliforms and villus height, serum cholesterol level and performance of broiler chickens. Afr. J. Biotechnol. 9:7564-7567.

Tasiemski, A. 2008. Antimicrobial peptides in annelids. Invertebr. Surviv. J. 5: 75-82.

Teo, A. Y. L \& H. M. Tan. 2006. Effect of Bacillus subtilis PB6 (CloSTAT) on broilers infected with a pathogenic strain of Escherichia coli1. J. Appl. Poult. Res. 15: 229-235.

Timmerman, H. M., A. Veldman, E. van den Elsen, F. M. Rombouts, \& A. C. Beynen. 2006. Mortality and growth performance of broilers given drinking water supplemented with chicken-specific probiotics. Poult. Sci. 5:1383-1388.

Ton, V. D., H. Q. Hanh, N. D. Linh, \& N. V. Duy. 2009. Use of redworms (Perionyx excavatus) to manage agricultural wastes and supply valuable feed for poultry. Livestock Research for Rural Development. Volume 21. Article \#192. http://www.lrrd.org/lrrd21/11/ton21192.htm. [23 September 2012]

Van Laack, R. L. J. M., C. H. Liu, M. O. Smith, \& H. D. Loveday. 2000. Characteristics of pale, soft, exudative broiler breast meat. Poult. Sci. 79:1057-1061.

Zhu, Y, L. Wei, \& Y. Zhang. 2010. Effect of earthworm powder substitution to fish meal on slaughter performance and meat quality of broilers. CNKI J. http://en.cnki.com.cn/Article_en/CJFDTOTAL-ZGJQ201019010.htm. [14 September 2012]. 